\title{
Testing the Olze and Timme Methods for Dental Age Estimation in Radiographs of Brazilian Subadults and Adults
}

\section{Ispitivanje metoda Olzea i Timmea za procjenu dobi zuba na ortopantomogramima brazilskih adolescenata i odraslih}

\footnotetext{
${ }^{1}$ Department of Social Odontology, Forensic Odontology Division, Piracicaba Dental School, State University of Campinas, Piracicaba, Brazil. Odjel za socijalnu stomatologiju - Odsjek za forenzičku stomatologiju Stomatološkog fakulteta Piracicaba Državnoga sveučilišta Campinas, Piracicaba, Brazil

2 Division of Forensic Dentistry, Faculdade São Leopoldo Mandic, Instituto de Pesquisas São Leopoldo Mandic, Campinas, Brazil. Odjel za sudsku stomatologiju fakulteta São Leopoldo Mandić, Campinas, Brazil

3 Department of Therapeutic Stomatology, Institute of Dentistry, Sechenov University.

Zavod za terapijsku stomatologiju Stomatološkoga fakulteta Sveučilišta Sechenov

4 Centre of Forensic and Legal Medicine and Dentistry, School of Dentistry, University of Dundee, United Kingdom.

Centar za sudsku i pravnu medicinu i stomatologiju Stomatološkog fakulteta Sveučilišta Dundee, Ujedinjeno Kraljevstvo

${ }^{5}$ Department of Federal Police, National Institute of Criminalistics, Brasília, Brazil.

Odjel federalne policije - Nacionalni institut za kriminalistiku, Brazílija, Brazil

6 Department of Forensic Medicine and Pathology, Faculty of Medicine of Ribeirão Preto, Ribeirão Preto, Brazil.

Zavod za sudsku medicinu i patologiju Medicinskog fakulteta Ribeirão Preto, Brazil

7 Department of Dentistry, Federal University of Paraíba, João Pessoa, Brazil.

Zavod za stomatologiju Federalnog sveučilišta Paraíba, João Pessoa, Brazil

8 Scientific Police of Paraiba, João Pessoa, Brazil.

Znanstvena policija Paraibe - João Pessoa, Brazil

9 Department of Social Odontology, Forensic Odontology Division, Piracicaba Dental School, State University of Campinas, Piracicaba, Brazil. Odjel za socijalnu odontologiju - Odsjek za forenzičku odontologiju Stomatološkog fakulteta Piracicaba Državnoga sveučilišta Campinas, Piracicaba, Brazil
}

\section{Abstract}

Aim: This study aimed to test the applicability of the methods proposed by Olze et al. (2012) and Timme et al. for dental age estimation in Brazilian subadults and adults. Material and methods: Panoramic radiographs of 503 individuals aged between 20 and 70 years were analyzed. The mean chronological age of males and females of the sample was 29.04 and 29.97 years, receptively. Secondary dentin formation, cementum apposition, periodontal recession, and attrition of teeth \#34, \#35, \#44 and \#45 teeth were assessed as parameters to be calculated in the formulae designed by Olze et al. and Timme et al. Results: In males, the mean estimated age by the Olze method was 28.97 \pm 2.86 years, while in females it was $27.85 \pm 2.70$ years. The Timme method estimated mean age for males of $32.54 \pm 5.32$ years and for females $33.09 \pm 5.16$ years. Low coefficients of determination $\left(r^{2}\right)$ for the application of tooth-specific formulae of both methods suggest that estimated and chronological ages were not properly associated. Conclusion: The outcomes of this study indicate that the Olze and Timme methods may be limited for forensic applications in Brazilian subadults and adults. Country-specific statistical adjustments might be useful for improvements in practice.
Received: April 12, 2021

Accepted: October 22, 2021

Address for correspondence Thaís Uenoyama Dezem University of Campinas Piracicaba Dental School, Department of Social Odontology, Forensic Dentistry Division Av. Limeira, 901, Piracicaba, Sao Paulo, Brazil, 13414-903.

Phone: +55 19 2106-5209 thaisdezem@yahoo.com.br MeSH terms: Age Determination by Teeth

Author keywords: Age Estimation; Dental Development; Forensic Dentistry; Radiology

\section{Introduction}

Dental age estimation of subadults usually relies on crown-root development observed on radiographs (1), computed tomography (2) and magnetic resonance imaging (3). The transition of subadults into adults manifests in human teeth when the third molars progressively reaches complete rhizogenesis. When this process is finished, dental age estimation becomes more challenging because in adults den-
Uvod

Procjena dobi zuba adolescenata obično se oslanja na razvoj korijena krunice koji se opaža na rendgenskim snimkama (1), kompjutoriziranoj tomografiji (2) i magnetskoj rezonanciji (3). Prelazak adolescenata u odrasle manifestira se u ljudskim zubima kada treći kutnjaci progresivno dosegnu potpunu apeksogenezu. Kada se taj proces završi, procjena dobi zuba postaje zahtjevnija jer njihov razvoj kod odraslih 
tal development is not an available parameter - instead, it is replaced by morphological information, such as secondary dentin formation, cementum apposition, periodontal recession, attrition, apical resorption and root translucency (4-8).

The use of morphological parameters for dental age estimation was firstly introduced by Gustafson in 1950 as an alternative to retrieve age information from fully developed teeth (9). The method was primarily destructive, as it required extraction and internal tooth examination - e.g. for assessing secondary dentin formation (9). For this reason, the morphological parameters suggested by the method were incorporated for forensic performances of the deceased.

Olze et al. (10) proposed an adaptation of the original Gustafson's method for use in panoramic radiographs of individuals aged 15-40 years. Considering premolars as the teeth with stronger association with chronological age, the authors classified four morphological parameters, namely secondary dentin formation, cementum apposition, periodontal recession and attrition (8). Furthermore, Timme et al. (11) updated the Olze method by extending the age interval from 15 to 70 years.

The present study was designed to test the applicability of the methods proposed by Olze et al. (10) and Timme et al. (11) for dental age estimation from panoramic radiographs of Brazilian subadults and adults.

\section{Material and methods}

\section{Study design and ethical aspects}

An observational study with retrospective sampling was performed with the approval of the Institutional Committee of Ethics in Human Research (protocol: 54456416.3.0000.5418).

\section{Sampling}

Sampling was performed by convenience from an existing image database of panoramic radiographs taken for dental treatment purposes. The inclusion criteria were panoramic radiographs from males or females, aged between 15 and 70 years, with at least one premolar visible for analysis. The exclusion criteria consisted of patients with premolars with large cavities, restorations and prosthetic appliances, severe bone loss, use of orthodontic appliances and the presence of periapical lesions.

The images were analyzed by a single examiner who was not aware of the age and sex of the sampled individuals. The analyses were performed in a personal computer by applied Olze's and Timme's method for dental age estimation. In order to test the applicability of the method in a better way, the sample was divided into the panoramic images of subjects aged between 15 and 40 years and those aged between 15 and 70 years. Age information was retrieved within both methods by assessing the stages of secondary dentin formation, periodontal recession, attrition and cementum apposition in the mandibular first and second premolars of the left (\#34 and 35, respectively) and right (\#44 and 45, respectively) sides. These parameters were classified into four progressive stages from 0 to 3 and incorporated in specific formu- nije dostupan parametar - umjesto toga, zamjenjuju ga morfološke informacije, kao što su formiranje sekundarnog dentina, apozicija cementa, parodontna recesija, atricija, apikalna resorpcija i prozirnost korijena $(4-8)$.

Korištenje morfoloških parametara za procjenu dobi zuba prvi je uveo Gustafson 1950. godine kao alternativu za dobivanje podataka o dobi iz potpuno razvijenih zuba (9). Metoda je bila destruktivna jer je zahtijevala vađenje i unutarnji pregled zuba - npr., za procjenu formiranja sekundarnog dentina (9). Zbog toga su morfološki parametri predloženi tom metodom ugrađeni u forenzičke izvedbe pokojnika.

Olze i suradnici (10) predložili su prilagodbu izvorne $\mathrm{Gu}$ stafsonove metode za korištenje u panoramskim radiografijama osoba u dobi od 15 do 40 godina. $S$ obzirom na pretkutnjake, kao zube $s$ jačom povezanošću $s$ kronološkom dobi, autori su klasificirali četiri morfološka parametra, a to su stvaranje sekundarnog dentina, apozicija cementa, parodontna recesija i atricija (8). Nadalje, Timme i suradnici (11) prilagodili su Olzeovu metodu produživši dobni interval s 15 na 70 godina.

Ova studija osmišljena je da bi se ispitala primjenjivost metoda koje su predložili Olze i suradnici (10) i Timme i suradnici (11) za procjenu dobi zuba na temelju panoramskih radiografija brazilskih adolescenata i odraslih.

\section{Materijal i metode}

\section{Dizajn studije i etički aspekti}

Provedbu studije odobrio je Institucionalni odbor za etiku u istraživanju ljudi (protokol: 54456416.3.0000.5418).

\section{Analiza uzoraka}

Analiza uzoraka obavljena je na temelju podataka iz postojeće baze panoramskih radiografskih snimki učinjenih za potrebe stomatološkog liječenja. Kriteriji za uključivanje bili su panoramske rendgenske snimke muškaraca ili žena u dobi između 15 i 70 godina s barem jednim vidljivim premolarom za analizu. Kriteriji za isključenje bili su pacijenti s pretkutnjacima s velikim kavitetima, restauracijama i protetičkim aparatima, teškim gubitkom kosti i periapikalnim lezijama, ili ako se koriste ortodontskim aparatima.

Slike je analizirao jedan ispitivač koji nije znao dob i spol analiziranih snimki. Analize su obavljene na osobnom računalu primijenjenom Olzeovom i Timmeovom metodom za procjenu dentalne dobi. Kako bi se što bolje ispitala primjenjivost metode, uzorak je podijeljen na panoramske slike ispitanika u dobi između 15 i 40 godina i onih od 15 do 70 godina. Podatci o dobi dobiveni su unutar obiju metoda procjenom faza formiranja sekundarnog dentina, parodontne recesije, atricije i apozicije cementa u prvom i drugom pretkutnjaku donje čeljusti lijevo (br. 34 i 35) i desno (br. 44 i 45, redom ). Ti su parametri razvrstani u četiri progresivna stupnja od 0 do 3 i ugrađeni u specifične formule $(10,11)$. Spol, kronološka dob i procijenjena starost zuba iz obiju metoda smatrani su varijablama za analizu podataka u ovoj studiji. 
lae $(10,11)$. Sex, chronological age and estimated dental age from both methods were considered variables for data analysis in this study.

\section{Risk of bias}

The risk of bias in this study was more strongly associated with intra- and inter-examiner errors. In order to minimize the errors, the main examiner (with nearly 7 years of experience with forensic odontology) was trained and calibrated for the methods. The main examiners repeated of the analysis with $15 \%$ of the main sample to enable intra-examiner agreement test. A second trained examiner (with nearly 7 years of experience with forensic odontology) was included. This examiner analyzed $15 \%$ of the sample, thus enabling an interexaminer agreement.

\section{Data analysis}

Examiner agreement was calculated with Kappa statistics. Intra- and inter-examiner agreement ranged above 0.8 $(\mathrm{p}<0.05)$. Descriptive statistics was used to assess the data related to mean chronological and estimated ages (according to the Olze's and Timme's methods). Measures of central tendency and dispersion were used. Linear regression analysis was the approach taken to compare chronological and estimated ages. Statistical significance was set at 5\%. Statistical analyses were performed with $\mathrm{R}$ software package (The $\mathrm{R}$ foundation, Vienna, Austria).

\section{Results}

Five-hundred and three panoramic radiographs $(\mathrm{n}=$ 1.598 premolars; $\# 34=464, \# 35=376, \# 44=413$ and $\# 45$ $=345)$ met the eligibility criteria. The sample was divided in age groups of participants aged between $15-40$ years ( $\mathrm{n}$ = 280; 145 females [mean age: 29.97 years] and 135 males [mean age: 29.04 years]) and between $15-70$ years $(\mathrm{n}=503$; 272 females [mean age: 39.86 years] and 231 males [mean age: 37.81 years]). In the group $15-40$, the quantity of teeth $\# 34, \# 35, \# 44$ and \#45 was 272, 269, 251 and 243, respectively. In the group $15-70$, the same teeth reached $n=464$, 376,413 and 345 , respectively.

The mean of ages estimated in males and females by the Olze method were of $28.97( \pm 2.86)$ and $27.85( \pm 2.70)$ years, respectively. Using the Timme method, the mean estimated ages in males and females were $32.54( \pm 5.23)$ and 33.09 $( \pm 5.16)$ years, respectively. The complete distribution of age in the study groups is presented in table 1 .

In the age group of $15-40$ years, the Olze method reached a percentage of method fitting of $1.5 \%$ within the age estimation

\section{Rizik od pristranosti}

Rizik od pristranosti u ovoj studiji bio je snažnije povezan $s$ pogreškama unutar ispitivača i među njima. Kako bi se pogreške svele na najmanju moguću mjeru, glavni ispitivač (s gotovo 7 godina iskustva u forenzičkoj stomatologiji) educiran je i kalibriran za metode. Glavni ispitivači ponovili su analizu na $15 \%$ uzoraka kako bi omogućili test slaganja unutar ispitivača. Uključen je i drugi educirani ispitivač (s gotovo 7 godina iskustva u forenzičkoj odontologiji). On je analizirao $15 \%$ uzoraka kako bi se eventualna pogreška smanjila na najmanju moguću mjeru.

\section{Analiza podataka}

Analiza pogreške među ispitivačima izračunata je Kappa testom. Slaganje unutar i među ispitivačima kretalo se iznad $0,8(\mathrm{p}<0,05)$. Deskriptivna statistika korištena je za procjenu podataka koji se odnose na srednju kronološku i procijenjenu dob (prema Olzeovoj i Timmeovoj metodi). Korištene su mjere središnje tendencije i disperzije. Linearna regresijska analiza korištena je za usporedbu kronološke i procijenjene dobi. Statistička značajnost postavljena je na $5 \%$. Statističke analize obavljene su u programskom paketu $\mathrm{R}$ (The $\mathrm{R}$ foundation, Beč, Austrija).

\section{Rezultati}

Kriterije prihvatljivosti zadovoljila su 503 ortopantomograma $(\mathrm{n}=1598$ pretkutnjaka; $\# 34=464, \# 35=376, \# 44$ $=413 \mathrm{i} \# 45$ = 345). Uzorak je podijeljen na dobne skupine sudionika u dobi između 15 i 40 godina [ $\mathrm{n}=280$; 145 žena (prosječna dob: 29,97 godina) i 135 muškaraca (prosječna dob: 29,04 godina)] i između 15 i 70 godina [ $\mathrm{n}=503$; 272 žene (srednja dob: 39,86 godina) i 231 muškarac (srednja dob: 37,81 godina)]. U skupini od 15 do 40 broj zuba \#34, \#35, \#44 i \#45 bio je 272, 269, 251 i 243. U skupini od 15 do 70 isti su zubi dosegnuli $n=464,376,413$ i 345 .

Prosječna dentalna dob procijenjena kod muškaraca i žena Olzeovom metodom iznosila je 28,97 $( \pm 2,86)$, odnosno $27,85( \pm 2,70)$ godina. Koristeći se Timmovom metodom, srednja procijenjena dob muškaraca i žena iznosila je 32,54 $( \pm 5,23)$, odnosno $33,09( \pm 5,16)$ godina. Potpuna raspodjela dobi u ispitivanim skupinama prikazana je u tablici 1 .

U dobnoj skupini od 15 do 40 godina Olzeova metoda postigla je postotak uklapanja metode od $1,5 \%$ u procesu procjene dobi sa zubom 35 i korišstenjem srednje vrijednosti

Table 1 Descriptive data of chronological and estimated dental ages based on Olze's and Timme's methods (Total sample, 15-70 years). Tablica 1. Opisni podatci kronološke i procijenjene dobi zuba na temelju Olzeovih i Timmeovih metoda (ukupni uzorak, 15-70 godina)

\begin{tabular}{|c|c|c|c|c|c|c|c|c|}
\hline Age • & Method• & Mean • & SD & Min. & Max. & Median & Q25 & Q75 \\
\hline Chronological • Kronološka & & 38.92 & 12.59 & 19.58 & 70 & 36.91 & 28.08 & 48.25 \\
\hline \multirow{2}{*}{ Estimated $\bullet$ Postignuta } & Olze's & 29.77 & 3.90 & 18.14 & 47.16 & 29.37 & 27.03 & 32.07 \\
\hline & Timme's & 32.55 & 5.74 & 11.31 & 52.07 & 32.41 & 29.08 & 36.10 \\
\hline
\end{tabular}


Table 2 Outcomes of the performance of the Olze method in the Brazilian population

Tablica 2. Ishodi izvedbe Olzeove metode u brazilskoj populaciji

\begin{tabular}{|c|c|c|c|c|c|c|}
\hline Age $\bullet$ & Tooth • & $\begin{array}{l}\text { Correlation } \\
\text { coefficient }\end{array}$ & Sig. & ${ }^{\mathrm{R}} 2$ & Error & Correction factor \\
\hline \multirow{5}{*}{$15-40$} & 34 & 0.087 & 0.077 & - & - & - \\
\hline & 35 & 0.122 & 0.023 & $1.5 \%$ & 5.62 & Age $=23.77+(0.19 *$ ID_35) +5.62 \\
\hline & 44 & 0.094 & 0.068 & - & - & - \\
\hline & 45 & 0.069 & 0.141 & - & - & - \\
\hline & Mean & 0.124 & 0.019 & $1.5 \%$ & 5.59 & Age $=22.53+\left(0.24^{*}\right.$ ID_Mean $)+5.59$ \\
\hline \multirow{5}{*}{$15-70$} & 34 & 0.416 & 0.000 & $17.3 \%$ & 10.94 & Age $=3.17+\left(1.17^{*}\right.$ ID_34 $)+10.94$ \\
\hline & 35 & 0.348 & 0.000 & $12.1 \%$ & 9.2 & Age $=8.23+\left(0.87 * I D \_35\right)+9.2$ \\
\hline & 44 & 0.406 & 0.000 & $16.5 \%$ & 10.92 & Age $=2.98+\left(1.17^{*}\right.$ ID_44 $)+10.92$ \\
\hline & 45 & 0.355 & 0.000 & $12.6 \%$ & 9.16 & Age $=9.06+\left(0.88^{*}\right.$ ID_45 $)+9.16$ \\
\hline & Mean & 0.477 & 0.000 & $22.7 \%$ & 11.08 & Age $=-9.76+(1.62 *$ ID_Mean $)+11.08$ \\
\hline
\end{tabular}

Sig. = significance. $\mathrm{R}^{2}=$ determination coefficient. 34: mandibular left first premolar; 35: mandibular left second premolar; 44: mandibular right first premolar; 45: mandibular right second premolar.

Table 3 Outcomes of the performance of the Timme method in the Brazilian population

Tablica 3. Rezultati izvedbe Timmeove metode u brazilskoj populaciji

\begin{tabular}{|c|c|c|c|c|c|c|}
\hline Age $\bullet$ & Tooth • & $\begin{array}{l}\text { Correlation } \\
\text { coefficient }\end{array}$ & Sig. & ${ }^{\mathrm{R}} 2$ & Error & Correction factor \\
\hline \multirow{5}{*}{$15-40$} & 34 & 0.117 & 0.027 & $1.4 \%$ & 5.61 & Age $=24.58+(0.17 *$ ID_34 $)+5.61$ \\
\hline & 35 & 0.165 & 0.003 & $2.7 \%$ & 5.58 & Age $=22.66+\left(0.24 * I D \_35\right)+5.58$ \\
\hline & 44 & 0.121 & 0.028 & $1.5 \%$ & 5.58 & Age $=24.87+\left(0.17 * I D \_44\right)+5.58$ \\
\hline & 45 & 0.089 & 0.083 & - & - & - \\
\hline & Mean & 0.166 & 0.003 & $2.8 \%$ & 5.56 & Age $=20.52+\left(0.33^{*}\right.$ ID_Mean $)+5.56$ \\
\hline \multirow{5}{*}{$15-70$} & 34 & 0.351 & 0.000 & $12.3 \%$ & 11.27 & Age $=16.88+\left(0.64 * I D \_34\right)+11.27$ \\
\hline & 35 & 0.296 & 0.000 & $8.8 \%$ & 9.37 & Age $=18.29+\left(0.49 * I D \_35\right)+9.37$ \\
\hline & 44 & 0.422 & 0.000 & $17.8 \%$ & 10.83 & Age $=12.40+(0.78 *$ ID_44 $)+10.83$ \\
\hline & 45 & 0.325 & 0.000 & $10.5 \%$ & 9.27 & Age $=18.21+(0.52 *$ ID_45 $)+9.27$ \\
\hline & Mean & 0.477 & 0.000 & $22.8 \%$ & 11.08 & Age $=1.23+\left(1.14^{*}\right.$ ID_Mean $)+11.08$ \\
\hline
\end{tabular}

Sig. = significance. $\mathrm{R}^{2}=$ determination coefficient. 34: mandibular left first premolar; 35: mandibular left second premolar; 44: mandibular right first premolar; 45: mandibular right second premolar.

process with tooth 35 and using the mean of measurements of premolars. In the age group of 15-70 years, the percentage of method fitting (applicability to the Brazilian population) was better than the age group of 15-40 years. Method fitting using all the teeth (and the mean of all premolar measurements) ranged between $12.1 \%$ and $22.7 \%$ (Table 2).

During the analysis of the Timme method, in the age group of $15-40$ years, the percentage of method fitting changed from $1.4 \%$ to $2.8 \%$. In this process, tooth \#45 was not correlated with age. In the age group of $15-70$ years, the percentage of method fitting changed from $8.8 \%$ to $22.8 \%$ (Table 3 ).

\section{Discussion}

Dental age estimation may be based on developmental $(12,13)$, morphological (14) and biochemical parameters (15). The choice for each of the parameters depends on each category of the individual under examination. Developmental information can be retrieved from the human teeth mjerenja pretkutnjaka. U dobnoj skupini od 15 do 70 godina postotak prilagodbe metode (primjenjivost na brazilsku populaciju) bio je bolji od dobne skupine od 15 do 40 godina. Metoda analize svih zuba (i srednja vrijednost svih mjerenja premolara) kretala se između $12,1 \%$ i 22,7 \% (tablica 2).

Tijekom analize Timmeovom metodom, u dobnoj skupini od 15 do 40 godina, postotak uklapanja metode promijenio se s $1,4 \%$ na $2,8 \%$. U ovom istraživanju zub \#45 nije bio u korelaciji s dobi. U dobnoj skupini od 15 do 70 godina postotak prilagodbe metode promijenio se $s \quad 8,8 \%$ na 22,8 $\%$ (tablica 3.).

\section{Rasprava}

Procjena dentalne dobi zuba može se temeljiti na razvojnim $(12,13)$, morfološkim (14) i biokemijskim parametrima (15). Izbor za svaki od njih ovisi o svakoj kategoriji pojedinca koji se ispituje. Informacije o razvoju mogu se dobiti iz ljudskih zuba od intrauterina života do rane odrasle dobi (16). U 
from intrauterine life to the early adulthood (16). In this time frame, deciduous, mixed and permanent dentitions offer valuable age information from stages of crown-root formation (1,17-20), measurements of open apices (21-23) and even bone or clinical eruption (24). After eruption in the oral cavity, the human teeth undergo progressive (and mostly degenerative) morphological changes, such as attrition. In particular, the morphological information have more important role in the adult group (4-11), in which the teeth have already finished their development. Morphological parameters can be assessed ex vivo, via destructive approach, or by means of radiology and imaging $(25,26)$. The biochemical parameters may be investigated and used for forensic purposes without restriction of age group. It depends, however, on the availability of advanced devices and facilities. The present study tested the performance of the Olze (10) and Timme (11) radiographic methods based on morphological parameters.

The methods used in this study retrieved radiographic age information from specific teeth, namely premolars. The choice for these teeth is justified based on technical and agerelated reasons. The technical reason relies on the fact that premolars are usually less superimposed with bones (i.e. vertebrae) in panoramic radiographs, and because they have a single root with a large and visible pulp chamber and a root canal. The age-related reason relies on previous studies that revealed a possible correlation of these teeth with chronological age (29). Other age estimation techniques may rely on different teeth and parameters $(30,31)$. In the present study, the correlation coefficient of premolars with chronological age ranged below moderate (between poor and fair) (32). These outcomes reflected in the mean error rates that were obtained from the comparison between chronological and estimated dental ages using the Olze and Timme methods. The performance of both methods was very similar in age groups $15-40$ and 15-70, with error rates of nearly 5.5 years and 11 years, respectively. The rationale behind the increase of error that almost doubled from group 15-40 to group 15-70 may have relied on the increase in the age interval - from 25 age intervals of one year in group 15-40 to 55 age intervals of one year in group 15-70. As the age intervals nearly doubled the size, the error proportionally followed the same tendency. These findings corroborate a recent study with the Olze method in the same population. According to the existing scientific literature (33), the Olze method is able to reach optimal error rates in individuals in the young and middle adulthood (up to 41 years), while worse estimates are obtained in latter ages. In practice, these outcomes direct the attention towards the decision-making process for selecting a method based on the target age group of the examined individual. Examples of age groups are children, subadults and adults (in case of the Olze and Timme methods). Each subgroup might be subdivided (i.e. young- or old adulthood) to facilitate the process of making more specific and optimal decisions about the method to be applied.

As age groups influenced on the decision for specific methods, so did the sex. In females the mean error according to the Olze method was 2.25 years below the mean er- tom razdoblju mliječne, mješovite i trajne denticije daju vrijedne podatke o dobi iz faza formiranja krune i korijena (1, $17-20)$, mjerenja otvorenih vrhova $(21-23)$ pa čak i koštane ili kliničke erupcije (24). Nakon nicanja u usnoj šupljini, ljudski zubi prolaze kroz progresivne (i uglavnom degenerativne) morfološke promjene, poput trošenja. Morfološke informacije posebno su važne za skupinu odraslih $(4-11)$ u kojoj su zubi već završili s razvojem. Morfološki parametri mogu se procijeniti ex vivo, destruktivnim pristupom ili radiološkim i slikovnim $(25,26)$. Biokemijski parametri mogu se istraživati i koristiti u forenzičke svrhe bez ograničenja dobne skupine. No to ovisi o dostupnosti naprednih uređaja i objekata. U ovoj studiji testirana je učinkovitost Olzeovih (10) i Timmeovih (11) radiografskih metoda na temelju morfoloških parametara.

Metode korištene u ovoj studiji dohvatile su radiografske podatke o dobi iz određenih zuba, odnosno pretkutnjaka. Izbor tih zuba opravdan je tehničkim i dobnim razlozima. Tehnički razlog oslanja se na činjenicu da su pretkutnjaci obično manje superponirani s kostima (tj. kralješcima) na panoramskim rendgenskim snimkama i jer imaju jedan korijen s velikom i vidljivom pulpnom komorom i korijenskim kanalom. Razlog vezan za dob oslanja se na prethodne studije koje su otkrile moguću korelaciju tih zuba s kronološkom dobi (29). Druge tehnike procjene dobi mogu se oslanjati na različite zube i parametre $(30,31)$. U ovom istraživanju koeficijent korelacije pretkutnjaka $s$ kronološkom dobi bio je ispod umjerenoga (između slaboga i poštenoga) (32). Ti rezultati odražavaju se u srednjim stopama pogrešaka koje su dobivene usporedbom između kronološke i procijenjene dobi zuba korištenjem Olzeove i Timmeove metode. Izvedba obiju metoda bila je vrlo slična u dobnim skupinama od 15 do $40 \mathrm{i}$ od 15 do 70, sa stopama pogreške od gotovo 5,5 godina, odnosno 11 godina. Razlog za povećanje pogreške koja se gotovo udvostručila iz skupine od 15 do 40 u skupinu od 15 do 70 , možda se oslanjalo na povećanje dobnog intervala - s 25 dobnih intervala od jedne godine u skupini od 15 do 40 na 55 dobnih intervala od jedne godine u skupini od 15 do 70 . Kako su se dobni intervali gotovo udvostručili, pogreška je proporcionalno slijedila istu tendenciju. Ti nalazi potvrđuju nedavnu studiju s Olzeovom metodom u istoj populaciji. Prema postojećoj znanstvenoj literaturi (33), Olzeovom metodom mogu se postići optimalne stope pogrešaka kod osoba u mlađoj i srednjoj odrasloj dobi (do 41 godine), a lošije procjene dobivaju se u kasnijoj dobi. U praksi ti ishodi usmjeravaju pozornost na proces donošenja odluke za odabir metode na temelju ciljane dobne skupine ispitivane osobe. Primjeri dobnih skupina su djeca, adolescenti i odrasli (u slučaju Olzeove i Timmeove metode). Svaka podskupina može biti podijeljena (tj. mlada ili starija odrasla dob) kako bi se olakšao proces donošenja konkretnijih i optimalnijih odluka o metodi koju treba primijeniti.

Kako su dobne skupine utjecale na odluku o određenim metodama, tako je utjecao i spol. Kod žena je srednja pogreška prema Olzeovoj metodi bila 2,25 godina ispod srednje pogreške prema Timmeovoj metodi. Kod muškaraca je razlika bila 1,57 godina. Prosječne pogreške unutar metode otkrile su znatno diskretniju razliku (0,17 godina - više kod že- 
ror according to the Timme method. For males, the difference was 1.57 years. Mean errors within method revealed a considerably discrete difference $(0.17$ years - higher in females) between females analyzed according to the Olze method. The difference increased within the Timme method $(0.82$ years - higher in females). These findings point out a primary outcome showing that the Olze method had a better performance among the individuals sampled in this study. Furthermore, it confirmed the need for specific formulae designed for females and males since the error rates between them vary. It must be noted, however, that the sampled distribution based on sex was slightly unequal (272 females and 231 males) in this study. Further studies in the field are encouraged to accomplish homogeneously distributed samples. The comparison of methods within different populations is recommended, as well as the development of specific formulae for populations in which the performance of the methods was not optimal.

\section{Conclusion}

Low coefficients of determination $\left(r^{2}\right)$ for the application of tooth-specific formulae of both methods suggest that estimated and chronological ages were not properly associated. The outcomes of this study indicate that the Olze and Timme methods may be limited for forensic applications in Brazilian subadults and adults. Because of sampling decisions, the outcomes of this study must be carefully interpreted because the age estimates were tested in age limits not originally included in the methods' interval.

\section{Conflict of interest}

The authors declare that they do not have conflict of interest related to the present study.

Authors' contributions: T.U.D. - Conceptualization, methodology, formal analysis, investigation, writing - original draft; A.F. - Conceptualization, methodology, data curation, writing - original draft; C.E.P.M., A.R.D., R.H.A.S. - Methodology, software, formal analysis, writing - original draft, visualization; B.M.S., I.L.A.R. - Conceptualization, methodology, investigation, data curation, writing - original draft, E.D.J. - Conceptualization, methodology, investigation, data curation, writing - original draft, supervision, project administration. na) između žena analiziranih prema Olzeovoj metodi. Razlika se povećala unutar Timmeove metode $(0,82$ godine - više kod žena).Ti nalazi upućuju na primarni ishod koji pokazuje da je Olzeova metoda imala bolji učinak među pojedincima uzorkovanima u ovoj studiji. Nadalje, potvrdila je potrebu za specifičnim formulama za žene i muškarce jer se stope pogrešaka između njih razlikuju. No mora se napomenuti da je uzorkovana distribucija na temelju spola bila u ovoj studiji malo nejednaka (272 žene i 231 muškarac). Potiču se daljnja istraživanja na terenu kako bi se postigli homogeno raspoređeni uzorci. Preporučuje se usporedba metoda unutar različitih populacija i na temelju specifičnih formula za populacije u kojima provedba metoda nije bila optimalna.

\section{Zaključak}

Niski koeficijenti determinacije $\left(\mathrm{r}^{2}\right)$ za primjenu formula specifičnih za zube u objema metodama sugeriraju da procijenjena dentalna i kronološka dob nisu pravilno povezane. Rezultati u ovoj studiji pokazuju da metode Olzea i Timmea mogu biti ograničene za forenzičku primjenu kod brazilskih adolescenata i odraslih osoba. Zbog odluka o uzorkovanju, rezultati iz ove studije moraju se oprezno tumačiti jer su procjene dobi testirane u dobnim granicama koje izvorno nisu bile uključene $\mathrm{u}$ interval metoda.

\section{Sukob interesa}

Autori nisu bili u sukobu interesa.

Doprinos autora: T. U. D. - konceptualizacija, metodologija, formalna analiza, istraživanje, pisanje izvornoga rada; A. F. - konceptualizacija, metodologija, prikupljanje podataka, pisanje izvornoga rada; C. E. P. M., A. R. D., R. H. A. S. - metodologija, softver, formalna analiza, pisanje izvornoga rada, vizualizacija; B. M. S., I. L. A. R. - konceptualizacija, metodologija, istraživanje, prikupljanje podataka, pisanje izvornoga rada; E. D. J. - konceptualizacija, metodologija, istraživanje, prikupljanje podataka, pisanje izvornoga rada, nadzor, administracija projekta.

\section{Sažetak}

Cilj: Željela se ispitati primjenjivost metoda koje su predložili Olze i suradnici (2012.) i Timme i suradnici za procjenu dobi zuba brazilskih adolescenata i odraslih. Materijal i metode: Analizirane su panoramske rendgenske snimke 503 osoba u dobi od 20 do 70 godina. Prosječna kronološka dob muškaraca i žena u uzorku bila je receptivno 29,04 i 29,97 godina. Sekundarni dentin, apozicija cementa, parodontna recesija i trošenje zuba \#34, \#35, \#44 i \#45 ocijenjeni su kao parametri koje treba izračunati u formulama koje su osmislili Olze i suradnici i Timme i suradnici. Rezultati: Kod muškaraca je srednja dob procijenjena Olzeovom metodom bila 28,97 $\pm 2,86$ godina, a kod žena je iznosila 27,85 $\pm 2,70$ godina. Timmeovom metodom procijenjena je srednja dob za muškarce od $32,54 \pm 5,32$ godine, a za žene $33,09 \pm 5,16$ godina. Niski koeficijenti determinacije $\left(r^{2}\right)$ za primjenu formula specifičnih za zube u objema metodama sugeriraju da procijenjena i kronološka dob nisu pravilno povezane. Zaključak: Rezultati ove studije pokazuju da Olzeova i Timmeova metoda mogu biti ograničene kad je riječ o forenzičkoj primjeni kod brazilskih adolescenata i odraslih osoba. Statističke prilagodbe za pojedine zemlje mogle bi biti korisne za poboljšanja u praksi.
Zaprimljen: 12. travnja 2021. Prihvaćen: 22. listopada 2021.

Adresa za dopisivanje

Thaís Uenoyama Dezem Sveučilište u Campinasu Stomatološki fakultet Piracicaba Zavod za socijalnu stomatologiju, Odjel za sudsku stomatologiju Av. Limeira, 901, Piracicaba, Sao Paulo, Brazil, 13414-903. telefon: +55 19 2106-5209 thaisdezem@yahoo.com.br

MeSH terms: određivanje dobi s pomoću zubi

Autorske ključne riječi: procjena dobi; razvoj zuba; forenzička stomatologija; radiologija 


\section{References}

1. Franco A, Vetter F, Coimbra EF, Fernandes Â, Thevissen P. Comparing third molar root development staging in panoramic radiography, extracted teeth, and cone beam computed tomography. Int J Legal Med. 2020 Jan;134(1):347-353.

2. Asif MK, Nambiar P, Ibrahim N, Al-Amery SM, Khan IM. Three-dimensional image analysis of developing mandibular third molars apices for age estimation: A study using CBCT data enhanced with Mimics \& 3-Matics software. Leg Med (Tokyo). 2019 Jul;39:9-14.

3. De Tobel J, Parmentier GIL, Phlypo I, Descamps B, Neyt S, Van De Velde WL, et al. Magnetic resonance imaging of third molars in forensic age estimation: comparison of the Ghent and Graz protocols focusing on apical closure. Int J Legal Med. 2019 Mar;133(2):583-592.

4. Bang G, Ramm E. Determination of age in humans from root dentin transparency. Acta Odontol Scand. 1970 Mar;28(1):3-35.

5. Solheim T, Sundnes PK. Dental age estimation of Norwegian adults--a comparison of different methods. Forensic Sci Int. JulAug 1980;16(1):7-17.

6. Johanson G. Age determination from teeth. Odontol Revy. 1971;22(Supp. 1):1-126.

7. Dalitz GD. Age determination of adult human remains by teeth examination. J Forensic Sci Soc. 1962;3(1):11-21.

8. Maples WR. An improved technique using dental histology for estimation of adult age. J Forensic Sci. 1978 Oct;23(4):764-70.

9. Gustafson G. Age determination on teeth. J Am Dent Assoc. 1950 Jul;41(1):45-54.

10. Olze A, Hertel J, Schulz R, Wierer T, Schmeling A. Radiographic evaluation of Gustafson's criteria for the purpose of forensic age diagnostics. Int J Legal Med. 2012 Jul;126(4):615-21.

11. Timme M, Timme WH, Olze A, Ottow C, Ribbecke S, Pfeiffer, Dettmeyer R, Schmeling A. Dental age estimation in the living after completion of third molar minieralization: new data for Gustafson's criteria. Int J Legal Med. 2017 Mar;131(2):569-577.

12. Bagic IC, Sever N, Brkic H, Kern J. Dental age estimation in children using orthopantomograms. Acta Stomatol Croat. 2007;42(1):1118.

13. Borcic I, Petrovecki M, Brkic H. Studies of two diferente methods for dental age estimation in Croatian children. Acta Stomatol Croat. 2006;40(2):135-141.

14. Brkic H, Milicevic M, Petrovecki M. Age Estimation methods using anthropological parameters on human teeth-(A0736). Forensic Sci Int. 2006 Oct 16;162(1-3):13-6.

15. Priyadarshini C, Puranik MP, Uma SR. Dental age estimation methods: a review. Int J Adv Health Sci. 2015;1(12):19-25.

16. Panchbhai AS. Dental radiographic indicators, a key to age estimation. Dentomaxillofac Radiol. 2011 May;40(4):199-212.

17. Franco A, Thevissen P, Fieuws S, Souza PH, Willems G. Applicability of Willems model for dental age estimations in Brazilian children. Forensic Sci Int. 2013 Sep 10;231(1-3):401.e1-4.

18. Kumagai A, Willems G, Franco A, Thevissen P. Age estimation combining radiographic information of two dental and four skeletal predictors in children and subadults. Int J Legal Med. 2018 Nov;132(6):1769-1777.
19. Ramaswami TB, da Rosa GC, Fernandes MM, de Oliveira RN, Tinoco RLR. Third molar development by Demirjian's stages and age estimation among Brazilians. Forensic Imag. 2020;20(1):200353.

20. Bittencourt MV, Cericato G, Franco A, Girão R, Lima APB, Paranhos L. Accuracy of dental development for estimating the pubertal growth spurt in comparison to skeletal development: a systematic review and meta-analysis. Dentomaxillofac Radiol. 2018 May;47(4):20170362.

21. Mazzilli LEN, Melani RFH, Lascala CA, Palacio LAV, Cameriere R. Age estimation: Cameriere's open apices methodology accuracy on a southeast Brazilian sample. J Forensic Leg Med. 2018 Aug;58:164-168.

22. Angelakopoulos N, De Luca S, Palacio LAV, Coccia E, Ferrante L, Pinchi V, Cameriere R. Age Estimation by measuring open apices in teeth: a new formula for two samples of South African black and white children. Int J Legal Med. 2019 Sep;133(5):1529-1536.

23. AlShahrani I, Yassin SM, Togoo RA, Tikare S, Khader MA, Alkahtani ZM. Age estimation by measurement of open apices in tooth roots: Study using Saudi Arabian samples. J Forensic Leg Med. 2019 Feb;62:63-68.

24. Singh K, Gorea RK, Bharti V. Age estimation from eruption of permanent teeth. J Ind Acad Forensic Med. 2005;27(4):231-235.

25. Balasuriya P, Doyle E. The use of dental CT for age profiling. J Forensic Radiol Imag. 2019;17(1):5-11.

26. Mazzilli LEN, Melani RFH, Lascala CA, Mariano GG, Sakaguti NM, Cameriere R. Radiological image processing advantages applied to human age estimation based on dental parameters. J Forensic Radiol Imag. 2019;17(1):12-17.

27. Lee SM, Oh S, Kim J, Kim YM, Choi YK, Kwak HH et al. Age estimation using the maxillary canine pulp/tooth ratio in Korean adults: A CBCT buccolingual and horizontal section image analysis. J Forensic Radiol Imag. 2017;9(1):1-5.

28. Cameriere R, De Luca S, Egidi N, Bacaloni M, Maponi P, Ferrante $L$ et al. Automatic age estimation in adults by analysis of canine pulp/tooth ratio: preliminary results. J Forensic Radiol Imag. 2015;3(1):61-66.

29. Cameriere R, Cunha E, Wasterlain SN, De Luca S, Sassaroli E, Pagliara F, Nuzzolese E, Cingolani M, Ferrante L. Age estimation by pulp/tooth ratio in lateral and central incisors by peri-apical Xray. J Forensic Leg Med. 2013;20(5):530-6.

30. Augusto D, Pereira CP, Rodrigues A, Cameriere R, Salvado F, Santos R. Dental age assessment by I2M and 13M: Portuguese legal age thresholds of 12 and 14 year olds. Acta Stomatol Croat. 2021 Mar;55(1):45-55.

31. Pereira CP, Russell LM, de Pádua Fernandes M, Alves da Silva RH, Vargas de Sousa Santos RF. Dental age estimation based on development dental atlas assessment in a child / adolescent population with systemic diseases. Acta Stomatol Croat. 2019;53(4):307-317.

32. Chan YH. Biostatistics 104: correlational analysis. Singapore Med J. 2003 Dec;44(12):614-9.

33. Lavez GP, Terada ASSD, Dezem TU, Galo R, Silva RHA. Age estimation using Olze's method in an adult Brazilian population. J Forensic Leg Med. 2017 Nov;52:241-244. 